\title{
Genetic Analysis of Quantitative Traits in Pepper (Capsicum annuum)
}

\author{
Arnon Ben-Chaim and Ilan Paran ${ }^{1}$ \\ Department of Plant Genetics and Breeding, Agricultural Research Organization, The Volcani Center, \\ Bet Dagan, P.O. Box 6, 50250, Israel
}

\begin{abstract}
AdDitional INDEX wORDs. quantitative inheritance, vegetable breeding, wide crosses
ABstract. Inheritance of 10 quantitative traits related to plant and fruit development was studied in an intraspecific cross between a bell-type 'Maor' [Capsicum annuum L. var. annuum (Grossum Group) 'Maor'] and a small-fruited pungent chilli line 'Perennial' [C. annuum var. annuum (Longum Group) 'Perennial']. Estimates of broad- and narrow-sense heritabilities, coefficients of genetic variance, and genotypic correlations were obtained from the segregation of $120 \mathrm{~F}_{3}$ families in 2 years. Three of the traits analyzed, days to first ripened fruit, plant height, and pedicel length, exhibited heterosis and transgressive segregation. Days to first ripened fruit and total soluble solids had low narrow-sense heritabilities. The other traits studied had moderate to high narrow-sense heritability estimates. Most of the genetic variation associated with traits that affect the size of the fruit and its shape was additive. The highest genetic correlation coefficients among pairs of traits were found between fruit weight and each of the three width characters: fruit diameter, pericarp thickness, and pedicel diameter. In contrast, fruit weight had a low correlation coefficient with fruit length, indicating that the size of the pepper fruit in this cross was determined primarily by its width.
\end{abstract}

Capsicum annuum is a variable pepper species comprising cultivated and wild accessions that differ in many yield and quality characters such as fruit shape, fruit weight, fruit color, pungency, plant height, and maturity. Exploitation of this variation for breeding sweet, large-fruited blocky-type peppers has, however, been limited and has ignored the vast variation that exists among wild and chilli accessions. Wild accessions have been used primarily to introgress genes that confer disease resistance into sweet blocky types (Caranta et al., 1997; Daubeze et al., 1995). Recently, the potential of wild species germplasm as a source of valuable yield and quality genes has been demonstrated in tomato (Lycopersicon sp.) and rice (Oryza sativa) through the use of molecular markers (Bernacchi et al., 1998; Xiao et al., 1996). These studies presented evidence that wild species, although inferior to modern cultivars, have favorable genes that are masked by other deleterious ones, but are capable of improving yield and quality of elite cultivars after being introgressed into them.

Many genetic studies of fruit characters in pepper have been reported in the past, however, in most cases only a few traits were included in each study (e.g., Deshpande, 1933; Khambanonda, 1950; Legg and Lippert, 1966; McArdle and Bouwkamp, 1983; Peterson, 1959; Thakur et al., 1980). Therefore, a comprehensive understanding of the relationships among the various traits could not be obtained.

To study the inheritance of fruit characters and to examine the potential of wild accessions of pepper as donors of valuable genes encoding agriculturally important traits, we crossed several smallfruited chilli accessions with sweet bell pepper lines. One such cross is between the bell-type 'Maor' [C. annuum var. annuum (Grossum Group) 'Maor'] and the domesticated Indian chilli-

Received for publication 21 June 1999. Accepted for publication 5 Oct. 1999 Contribution no. 109/99 of the Agricultural Research Organization, The Volcani Center, Bet Dagan, Israel. We thank A. Cahaner and J. Elkind of The Hebrew University of Jerusalem for assistance with statistical analyses. Support for this study was provided by a grant from the Binational Agricultural Research and Development (BARD) Fund (no. IS-2389-94). The cost of publishing this paper was defrayed in part by the payment of page charges. Under postal regulations, this paper therefore must be hereby marked advertisement solely to indicate this fact.

${ }^{1}$ To whom reprint requests should be addressed; e-mail vcparan@ @etvision.net.il. type inbred 'Perennial' [C. annuum var. annuum (Longum Group) 'Perennial']. 'Perennial' is characterized by small pungent fruit and resistance to important diseases such as cucumber mosaic virus (CMV), potato virus Y (PVY), and anthracnose (Singh, 1992). Although 'Perennial' is not a wild accession, it was chosen for this cross because it is one of the accessions most distantly related to the sweet blocky-type cultivars within $C$. annuum var. annuum (Paran et al., 1998). Furthermore, 'Perennial' is also being used as a source for breeding CMV-tolerant blocky-type peppers (Lapidot et al., 1997) and it has been used as a parent in a $C$. annuum var. annuum cross to construct a molecular markers map of pepper (Lefebvre et al., 1995). In the present paper we report on the biometrical analysis of quantitative traits associated with plant and fruit development that segregated among the progenies resulting from a cross between 'Maor' and 'Perennial'.

\section{Materials and Methods}

Plant material. An intraspecific $\mathrm{F}_{2}$ population was constructed from a cross of the two inbred pepper lines 'Maor' and 'Perennial'. Seeds of 'Maor' were obtained from C. Shifriss, The Volcani Center, Bet Dagan, Israel and those of 'Perennial' were obtained from A. Palloix, Institut National de la Agronomiqe (INRA), Montfavet, France. Two hundred thirty $\mathrm{F}_{2}$ plants, originated from a single $F_{1}$, were grown in a greenhouse in 1995 and were selfed to obtain $\mathrm{F}_{3}$ seeds. A subset of 120 randomly chosen $\mathrm{F}_{3}$ families underwent the biometrical analysis reported in this study.

EXPERIMENTAL DESIGN. Fifteen plants from each $\mathrm{F}_{3}$ family, and 45 plants from each of the two parents and their $F_{1}$ were grown in the field in Qiryat Gat, Israel, during Summers 1996 and 1997. Individual plants were spaced $30 \mathrm{~cm}$ apart in rows spaced $100 \mathrm{~cm}$ apart. The experiment was arranged in a randomized complete block design with 15 replications. Each replication consisted of a single plant from each of the $120 \mathrm{~F}_{3}$ families, and three plants of each of the parents and $F_{1}$. The populations were planted in April 1996 and 1997 and three fruit from each plant were harvested 90 d after planting.

Data Collection. Plants were measured for the following traits: 1) days to first ripened fruit, measured as the number of 
days from planting; data were taken at eight 3-d intervals during a period of 4 weeks starting $70 \mathrm{~d}$ after planting; 2) plant height, measured as the distance in centimeters from the base of the plant to its top taken $45 \mathrm{~d}$ after planting; 3 ) fresh fruit weight in grams; 4) soluble solids concentration, expressed as percent and measured with a refractometer in a drop of fresh juice extracted with a garlic crusher; 5) fruit length, measured as the distance in millimeters from the pedicel attachment to its apex; 6) fruit diameter, measured in millimeters at the maximum width; 7) fruit shape, calculated as the ratio of fruit length to fruit diameter; 8) pedicel length, measured in millimeters as the distance between the points of attachment to the stem and to the fruit; 9) pedicel diameter, measured in millimeters at the maximum width; and 10) pericarp thickness, measured in $\mathrm{mm}$ at its maximum width. All fruit and pedicel dimensions were measured with a digital caliper.

Statistical Analysis. All analyses were performed using JMP statistical software, version 3.1 for Macintosh (SAS Institute, Inc., 1995). Heritability estimates were calculated according to Cahaner and Hillel (1980). Broad-sense heritability $\left(\mathrm{h}^{2}{ }_{\mathrm{BS}}\right)$ was estimated by subtracting the environmental variances of the nonsegregating generations ('Perennial' and $\mathrm{F}_{1}$ ) from the segregating generation $\left(\mathrm{F}_{3}\right)$.

$$
h_{B S}^{2}=\frac{\left(V_{F_{3}}-V_{P}\right)}{V_{F_{3}}}
$$

where

$$
V_{p}=\frac{\left(V_{p_{1}}+V_{F_{1}}\right)}{2}
$$

Narrow-sense heritability $\left(\mathrm{h}^{2}{ }_{\mathrm{NS}}\right)$ was obtained by determining the components of variance $\left(\mathrm{s}_{\mathrm{b}}{ }_{\mathrm{b}}=\right.$ variance between $\mathrm{F}_{3}$ families; $\mathrm{s}^{2}{ }_{\mathrm{w}}=$ variance within $\mathrm{F}_{3}$ families) from one-way analysis of variance:

$$
h_{N S}^{2}=\frac{3 \sigma_{b}^{2}}{2 \sigma_{b}^{2}+\sigma_{w}^{2}}
$$

The expectations for these variances are $\mathrm{s}_{\mathrm{b}}^{2}=\mathrm{V}_{\mathrm{A}}+1 / 4 \mathrm{~V}_{\mathrm{D}}$ and $\mathrm{s}^{2}{ }_{\mathrm{w}}=1 / 2 \mathrm{~V}_{\mathrm{A}}+1 / 2 \mathrm{~V}_{\mathrm{D}}+\mathrm{V}_{\mathrm{E}}$ where $\mathrm{V}_{\mathrm{A}}$ is the additive variance, $\mathrm{V}_{\mathrm{D}}$ is the dominance variance, and $\mathrm{V}_{\mathrm{E}}$ is the environmental variance. Because the numerator in the narrow-sense heritability equation contains a portion of dominance variance $\left(3 / 8 \mathrm{~V}_{\mathrm{D}}\right)$, this estimate is biased upwards.

Coefficient of genetic variation (cv) was calculated as the genetic standard deviation divided by the $\mathrm{F}_{3}$ generation mean $\left(\bar{X}_{F_{3}}\right)$ :

$$
c v=\frac{\sqrt{\frac{3}{2} \sigma_{b}^{2}}}{\bar{X}_{F_{3}}} x 100
$$

Genotypic correlations $\left(r_{G f_{3}}\right)$ were estimated from the data obtained from the $\mathrm{F}_{3}$ generation:

$$
r_{G f_{3}}=\frac{\boldsymbol{\sigma}_{b(x, y)}}{\boldsymbol{\sigma}_{b(x)} \boldsymbol{\sigma}_{b(y)}}
$$

where $s_{b(x, y)}$ is the covariance between $F_{3}$ families for the traits $\mathrm{x}$ and $\mathrm{y}$, while $\mathrm{s}_{\mathrm{b}(\mathrm{x})}$ and $\mathrm{s}_{\mathrm{b}(\mathrm{y})}$ are the standard deviations for the variance between $\mathrm{F}_{3}$ families for traits $\mathrm{x}$ and $\mathrm{y}$.

\section{Results}

Mean, standard error, and variance, estimates of each of the traits in the four generations are presented in Table 1. Broad-sense and narrow-sense heritability and coefficient of genetic variance estimates are presented in Table 2 . All traits exhibited a significant $(P$ $<0.01)$ family $\times$ year interaction. Therefore, all estimates for the 2 years are presented separately. Data for six traits, i.e., fruit weight, fruit length, fruit diameter, pedicel length, pericarp thickness, and fruit shape were log-transformed because of lack of variance homogeneity. However, because the relative positions of the generation means on the scale and the estimates of the genetic parameters (heritability, and correlations) did not change, only the nontransformed data were used for the analyses in this study.

DAYS TO FIRST RIPENED FRUIT. 'Maor' set fruit significantly earlier than 'Perennial', while their $F_{1}$ exhibited heterosis towards earliness (the $\mathrm{F}_{1}$ mean was higher than the parental means in both years). Plants with lower and higher values than the two parents were observed in the $F_{3}$, indicating a transgressive segregation for this trait. Broad-sense heritability was moderate (0.58 and 0.66 in 1996 and 1997, respectively) compared with low narrow-sense heritability $(0.4$ and 0.27$)$, indicating a large environmental component of the phenotypic variation. Similarly, the very low value of the coefficient of genetic variation (3\% and $2 \%)$, indicated there was only a small proportion of additive genetic variation within the total phenotypic variation.

Plant height. 'Perennial' was significantly taller than 'Maor', while the $F_{1}$ exhibited heterosis over 'Perennial' in both years. Plants taller than 'Perennial' were observed in the segregating population, indicating a transgressive segregation for this trait. The low broadsense heritability values $(0.42$ and 0.2$)$ and the low coefficient of genetic variation $(11 \%$ and $12 \%)$, indicated a major environmental effect on the phenotypic variance for this trait.

Fruit WeIGHT. Fruit of the two parents exhibited a very large difference in their weight. The mean weight of the $F_{1}$ fruit indicated dominance of alleles coding for decreased fruit weight. The distribution of fruit weight in the segregating generation was skewed towards small fruit, with maximum fruit weight of $46 \mathrm{~g}$. Both broadsense heritability (0.97 in both years) and narrow-sense heritability estimates (1.0 and 0.79) were high. Similarly, the coefficient of genetic variation was very high (50\% in both years). These data indicate a small environmental and large additive genetic components of the phenotypic variation for this trait.

Fruit DIAMETER. This trait segregated in a manner similar to fruit weight, i.e., dominance of narrow fruit and high estimates of heritability and coefficient of genetic variation $(0.99,0.95$, and $32 \%$ for broad-sense heritability, narrow-sense heritability, and coefficient of genetic variation in 1996, respectively; 0.96, 0.92, and 30\% for broad-sense heritability, narrow-sense heritability, and coefficient of genetic variation in 1997, respectively). Therefore, most of the phenotypic variation of this trait is additive.

Fruit Length. 'Maor' had significantly longer fruit than 'Perennial'. The value of the $\mathrm{F}_{1}$ fruit length indicated dominance of alleles coding for increased fruit length. Plants with shorter fruit than those of 'Perennial' and longer ones than those of 'Maor' were recovered in the $\mathrm{F}_{3}$ generation, indicating a transgressive segregation for this trait. The broad-sense heritability was high in both years $(0.92$ and 0.85 in 1996 and 1997, respectively). The narrow-sense heritability 
was moderate to high in both years (0.76 and 0.68 in 1996 and 1997 , respectively). The coefficients of genetic variation were moderate (23\% and 22\% in 1996 and 1997, respectively). These data indicate a major additive and a relatively low environmental and dominance components of the phenotypic variation for this trait.

Fruit SHAPE. Fruit shape was defined as the ratio of fruit length to fruit diameter. 'Maor' had large fruit with nearly equal length and width. 'Perennial' had an elongated fruit while the fruit shape of the $\mathrm{F}_{1}$ closely resembled that of 'Perennial' indicating dominance of the high shape index (elongated fruit). Narrow-sense heritability for fruit shape was high (1.0 and 0.87 in 1996 and 1997, respectively). Variances of the parents and $\mathrm{F}_{1}$ generations, and, therefore, broadsense heritability for this trait could not be determined because length and width in these generations were based on the generation mean and not on means of individual plants. The coefficient of genetic variation was high $(41 \%$ and $39 \%$ in 1996 and 1997, respectively). The high estimates of heritability and coefficient of genetic variation, indicated that most of the phenotypic variation for this trait is additive.

PericarPthickness. The two parents differed significantly from each other in their pericarp thickness. The means of the $F_{1}$, and $F_{3}$ generations indicated dominance of the thin pericarp. The estimates of broad-sense and narrow-sense heritability were high in both years ( 0.84 and $0.83 ; 0.78$ and 0.7 for broad-sense heritability and narrowsense heritability, respectively), indicating a low environmental and large additive variance components in the phenotypic variation for this trait.

Total SOLuble solids. 'Perennial' had a significantly higher soluble solids concentration than 'Maor'. The mean of the $F_{1}$ indicated dominance of the high total soluble solids value. Broadsense and narrow-sense heritability estimates were moderate in 1996 (0.77 and 0.54, respectively), and were low in 1997 (0.43 and $0.24)$. The coefficient of genetic variance was low in both years $(7 \%$ and 8\% in 1996 and 1997, respectively). These values indicate a large environmental and nonadditive components in the phenotypic variation for this trait.

Pedicel Diameter. The two parents differed significantly from each other in pedicel diameter. Means of the $F_{1}$ and $F_{3}$ generations indicated dominance of the narrow pedicel. Heritability and coefficient of genetic variance estimates were moderate in both years

Table 1. Means, standard errors (SEs), and variances of quantitative traits in an intraspecific cross of Capsicum annuum L. var. annuum (Grossum Group) 'Maor' with C. annuum var. annuum (Longum Group) 'Perennial'.

\begin{tabular}{|c|c|c|c|c|c|c|c|c|c|c|}
\hline Generation & $\begin{array}{l}\text { Days } \\
\text { to first } \\
\text { ripened } \\
\text { fruit }\end{array}$ & $\begin{array}{c}\text { Plant } \\
\text { ht } \\
(\mathrm{cm})\end{array}$ & $\begin{array}{c}\text { Fruit } \\
\text { wt } \\
(\mathrm{g})\end{array}$ & $\begin{array}{l}\text { Fruit } \\
\text { diam } \\
(\mathrm{mm})\end{array}$ & $\begin{array}{c}\text { Fruit } \\
\text { length } \\
(\mathrm{mm})\end{array}$ & $\begin{array}{c}\text { Fruit } \\
\text { shape }^{\mathrm{z}}\end{array}$ & $\begin{array}{c}\text { Pericarp } \\
\text { thickness } \\
(\mathrm{mm})\end{array}$ & $\begin{array}{c}\text { Soluble } \\
\text { solids } \\
\text { concn } \\
(\%)\end{array}$ & $\begin{array}{c}\text { Pedical } \\
\text { diam } \\
(\mathrm{mm})\end{array}$ & $\begin{array}{c}\text { Pedical } \\
\text { length } \\
(\mathrm{mm})\end{array}$ \\
\hline \multicolumn{11}{|l|}{ 'Maor' 96} \\
\hline Mean & $136 b^{y}$ & $32.5 \mathrm{~d}$ & $155.6 \mathrm{a}$ & $77.1 \mathrm{a}$ & $77 \mathrm{a}$ & 1.0 & $4.8 \mathrm{a}$ & $8.1 b$ & $9 \mathrm{a}$ & $30 \mathrm{~b}$ \\
\hline SE & 0.8 & 1.1 & 8.1 & 1.56 & 1.8 & --- & 0.09 & 0.49 & 0.38 & 0.9 \\
\hline Variance & 12.6 & 17.9 & 196.3 & 51.4 & 6.8 & --- & 0.18 & 0.72 & 3 & 1.8 \\
\hline \multicolumn{11}{|l|}{ 'Maor' 97} \\
\hline Mean & $133 \mathrm{~b}$ & $29.2 \mathrm{~d}$ & $130 \mathrm{a}$ & $77.1 \mathrm{a}$ & $73 \mathrm{a}$ & 0.95 & $4.7 \mathrm{a}$ & $7.8 \mathrm{c}$ & $9.4 \mathrm{a}$ & $27 \mathrm{c}$ \\
\hline $\mathrm{SE}$ & 0.6 & 0.6 & 3.1 & 1.5 & 1.3 & --- & 0.04 & 0.25 & 0.15 & 0.6 \\
\hline Variance & 5.9 & 23 & 695 & 51.4 & 12.5 & --- & 0.18 & 1.6 & 1.8 & 2.3 \\
\hline \multicolumn{11}{|l|}{ 'Perennial' 96} \\
\hline Mean & $143 \mathrm{a}$ & $43.4 \mathrm{c}$ & $0.74 \mathrm{~d}$ & $6.8 \mathrm{~d}$ & $32 \mathrm{~d}$ & 4.7 & $0.8 \mathrm{~d}$ & $10.9 \mathrm{a}$ & $1.2 \mathrm{c}$ & $26 \mathrm{c}$ \\
\hline SE & 1.4 & 1 & 0.17 & 0.1 & 0.1 & --- & 0.02 & 0.26 & 0.02 & 0.4 \\
\hline Variance & 29.5 & 19.9 & 0.11 & 0.67 & 0.6 & --- & 0.02 & 0.28 & 0.03 & 1 \\
\hline \multicolumn{11}{|l|}{ 'Perennial' 97} \\
\hline Mean & $146 \mathrm{a}$ & $38.0 \mathrm{c}$ & $1.6 \mathrm{~d}$ & $6.8 \mathrm{~d}$ & $31 \mathrm{~d}$ & 4.5 & $0.9 \mathrm{~d}$ & $11.3 \mathrm{a}$ & $1.3 \mathrm{c}$ & $27 \mathrm{c}$ \\
\hline SE & 0.9 & 1.1 & 0.05 & 0.11 & 0.5 & --- & 0.02 & 0.37 & 0.03 & 0.5 \\
\hline Variance & 14.7 & 47 & 0.04 & 0.68 & 1.4 & --- & 0.04 & 1.36 & 0.2 & 1.7 \\
\hline \multicolumn{11}{|l|}{$\mathrm{F}_{1} 96$} \\
\hline Mean & $127 \mathrm{c}$ & $64.1 \mathrm{a}$ & $9.1 \mathrm{c}$ & $17.7 \mathrm{c}$ & $67 \mathrm{~b}$ & 3.7 & $1.9 \mathrm{c}$ & $10.1 \mathrm{a}$ & $2.7 \mathrm{~b}$ & $30 \mathrm{~b}$ \\
\hline $\mathrm{SE}$ & 0 & 1.4 & 0.58 & 0.23 & 0.8 & --- & 0.03 & 0.17 & 0.08 & 0.5 \\
\hline Variance & 0 & 38 & 1.4 & 2.9 & 3.4 & --- & 0.05 & 0.12 & 0.4 & 1.4 \\
\hline \multicolumn{11}{|l|}{$\mathrm{F}_{1} 97$} \\
\hline Mean & $128 \mathrm{c}$ & $55.9 \mathrm{a}$ & $10.2 \mathrm{c}$ & $17 \mathrm{c}$ & $65 \mathrm{~b}$ & 4.1 & $2.1 \mathrm{c}$ & $10 \mathrm{~b}$ & $3 \mathrm{~b}$ & $36 a$ \\
\hline SE & 0.5 & 0.9 & 0.28 & 0.23 & 0.9 & --- & 0.02 & 0.28 & 0.01 & 0.54 \\
\hline Variance & 4.1 & 46 & 2.1 & 2.9 & 6 & --- & 0.04 & 1.4 & 0.2 & 1.7 \\
\hline \multicolumn{11}{|l|}{$\mathrm{F}_{3} 96$} \\
\hline Mean & $135 \mathrm{~b}$ & $48.5 \mathrm{~b}$ & $11.4 \mathrm{~b}$ & $20.5 \mathrm{~b}$ & $61 \mathrm{c}$ & 3.2 & $2.1 \mathrm{~b}$ & $9.8 \mathrm{ab}$ & $2.5 \mathrm{~b}$ & $32 \mathrm{a}$ \\
\hline SE & 0.12 & 0.14 & 0.26 & 0.08 & 0.2 & 0.05 & 0.01 & 0.03 & 0.01 & 0.1 \\
\hline Variance & 32.3 & 50 & 32.8 & 47.4 & 27 & 1.4 & 0.24 & 0.9 & 0.62 & 5.2 \\
\hline \multicolumn{11}{|l|}{$\mathrm{F}_{3} 97$} \\
\hline Mean & $136 \mathrm{~b}$ & $42.6 \mathrm{~b}$ & $11.4 \mathrm{~b}$ & $21 \mathrm{~b}$ & $59 \mathrm{c}$ & 3 & $2.2 \mathrm{~b}$ & $9.6 \mathrm{~b}$ & $3 \mathrm{~b}$ & $35 \mathrm{~b}$ \\
\hline $\mathrm{SE}$ & 0.1 & 0.2 & 0.15 & 0.16 & 0.4 & 0.03 & 0.04 & 0.04 & 0.02 & 0.2 \\
\hline Variance & 26.6 & 58.6 & 40.2 & 45.4 & 25 & 1.2 & 0.2 & 2.6 & 0.6 & 5 \\
\hline
\end{tabular}

${ }^{\mathrm{z}}$ Ratio of fruit length to fruit diameter.

y Mean separation within columns by LSD, $P<0.01$. 
$(0.66,0.66$, and $24 \%$ in $1996 ; 0.77,0.63$, and $20 \%$ in 1997 for broadsense heritability, narrow-sense heritability and coefficient of genetic variance, respectively). These estimates suggest a large environmental variance component and that most of the genetic variation for this trait is additive.

Pedicel Length. The two parents had fruit with similar pedicel lengths while the means of the $F_{1}$, and $F_{3}$ generations were significantly higher, indicating heterosis towards long pedicels. Plants of $\mathrm{F}_{3}$ generations with longer pedicels than the parents were recovered, indicating a transgressive segregation for this trait. Broad-sense, and narrow-sense heritabilities and the coefficient of genetic variance were moderate $(0.77,0.5$, and $16 \%$ in 1996 , respectively; $0.66,0.68$, and $16 \%$ in 1997, respectively). These estimates suggest a considerable proportion of the phenotypic variation is environmental, while most of the genetic variation is additive.

The genetic correlations for all traits in both years are presented in Table 3. The two correlation estimates for each pair of traits were of similar magnitudes. However, for traits such as fruit weight and total soluble solids, the 1996 estimates were lower than those of 1997.

The most notable correlation estimates were the high positive correlations of fruit weight with the fruit width traits, i.e., fruit diameter, pedicel diameter, and pericarp thickness $(0.89,0.85$, and 0.85 in 1997, respectively). In contrast, fruit weight had much lower positive correlations with the fruit length traits, i.e., fruit length and pedicel length in both years. Fruit weight had moderate negative correlations with plant height, total soluble solids, and elongated fruit shape in both years. While the fruit width traits were highly correlated with each other, the fruit length traits had low correlation between themselves. Similarly, correlations between plant height and fruit length and between plant height and pedicel length were low. Days to first ripened fruit was negatively correlated with plant height as well as with fruit length and with elongated fruit shape. Total soluble solids content was negatively correlated with pericarp thickness, fruit weight, and fruit diameter.

\section{Discussion}

All the traits examined in this study exhibited continuous variation and therefore were inherited quantitatively. One trait, fruit shape had a bimodal distribution in the $\mathrm{F}_{3}$ generation, suggesting involvement of a major partly dominant gene in the genetic control of the trait. This observation is in agreement with previous studies in which fruit shape (measured as a length to width ratio) in both $C$. frutescens $L$. (tabasco pepper) and $C$. annuum was determined to be controlled by a single gene (Kaiser, 1935; Khambanonda, 1950; Peterson, 1959). Other studies, however, indicated a quantitative polygenic inheritance for this trait (McArdle and Bouwkamp, 1983).

Three traits (days to first ripened fruit, plant height, and pedicel length) exhibited transgressive segregation as well as heterosis. Earlier genetic studies in which these traits were examined also indicated heterosis for plant height (Thakur et al., 1980), fruit maturity (Lippert, 1975), plant height, and days to flower (Meshram and Mukewar, 1986). To our knowledge, only a single study has reported the inheritance of pedicel length in pepper (Setiamihardja and Knavel, 1990). In the latter study heterosis was not observed in the three $C$. annuum crosses analyzed.

Two traits had low broad-sense heritability estimates in the present study (plant height and total soluble solids in 1997). Therefore, environmental factors have a profound effect on these traits, which may hinder progress in selection for progeny containing favorable genes originated from 'Perennial'. Three traits (days to first ripened fruit, plant height, and total soluble solids) had a major dominance variance component, as revealed by the large difference between estimates of broad-sense and narrow-sense heritabilities in 1997 and by heterosis of the $F_{1}$. In contrast, characters that determined size and shape of the mature fruit were highly heritable and their genetic variance was mostly additive. Therefore, using 'Perennial' as a source for favorable genes, such as for tolerance to CMV

Table 2. Broad-sense heritability, narrow-sense heritability, and coefficient of genetic variation for quantitative traits in an intraspecific cross of Capsicum annuum L. var. annuum (Grossum Group) 'Maor' with C. annuum var. annuum (Longum Group) 'Perennial'.

\begin{tabular}{|c|c|c|c|c|}
\hline Trait & Year & $\begin{array}{c}\text { Broad-sense } \\
\text { heritability }\end{array}$ & $\begin{array}{c}\text { Narrow-sense } \\
\text { heritability }\end{array}$ & $\begin{array}{c}\text { Coefficient of } \\
\text { genetic variation }\end{array}$ \\
\hline \multirow[t]{2}{*}{ Days to first ripened fruit } & 1996 & 0.58 & 0.40 & 3 \\
\hline & 1997 & 0.66 & 0.27 & 2 \\
\hline \multirow[t]{2}{*}{ Plant height $(\mathrm{cm})$} & 1996 & 0.42 & 0.60 & 11 \\
\hline & 1997 & 0.20 & 0.43 & 12 \\
\hline \multirow[t]{2}{*}{ Fruit weight (g) } & 1996 & 0.97 & 1.00 & 50 \\
\hline & 1997 & 0.97 & 0.79 & 50 \\
\hline \multirow[t]{2}{*}{ Fruit diameter (mm) } & 1996 & 0.99 & 0.95 & 32 \\
\hline & 1997 & 0.96 & 0.92 & 30 \\
\hline \multirow[t]{2}{*}{ Fruit length (mm) } & 1996 & 0.92 & 0.76 & 23 \\
\hline & 1997 & 0.85 & 0.68 & 22 \\
\hline \multirow{2}{*}{ Fruit shape ${ }^{z}$} & 1996 & --- & 1.00 & 41 \\
\hline & 1997 & --- & 0.87 & 39 \\
\hline \multirow[t]{2}{*}{ Pericarp thickness (mm) } & 1996 & 0.84 & 0.78 & 20 \\
\hline & 1997 & 0.83 & 0.70 & 18 \\
\hline \multirow[t]{2}{*}{ Soluble solids concentration (\%) } & 1996 & 0.77 & 0.54 & 7 \\
\hline & 1997 & 0.46 & 0.24 & 8 \\
\hline \multirow[t]{2}{*}{ Pedicel diameter (mm) } & 1996 & 0.66 & 0.66 & 24 \\
\hline & 1997 & 0.77 & 0.63 & 20 \\
\hline \multirow[t]{2}{*}{ Pedicel length (mm) } & 1996 & 0.77 & 0.50 & 16 \\
\hline & 1997 & 0.66 & 0.68 & 16 \\
\hline
\end{tabular}

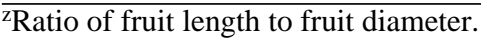


Table 3. Genotypic correlations among quantitative traits in an intraspecific cross of Capsicum annuum L. var. annuum (Grossum Group) 'Maor' with C. annuum var. annuum (Longum Group) 'Perennial' in 1996 (above diagonal) and in 1997 (below diagonal).

\begin{tabular}{|c|c|c|c|c|c|c|c|c|c|c|}
\hline Trait & $\begin{array}{c}\text { Days } \\
\text { to first } \\
\text { ripened } \\
\text { fruit }\end{array}$ & $\begin{array}{c}\text { Plant } \\
\text { ht } \\
(\mathrm{cm})\end{array}$ & $\begin{array}{c}\text { Fruit } \\
\text { wt } \\
(\mathrm{g})\end{array}$ & $\begin{array}{l}\text { Fruit } \\
\text { diam } \\
(\mathrm{mm})\end{array}$ & $\begin{array}{c}\text { Fruit } \\
\text { length } \\
(\mathrm{mm})\end{array}$ & $\begin{array}{c}\text { Fruit } \\
\text { shape }^{z}\end{array}$ & $\begin{array}{c}\text { Pericarp } \\
\text { thickness } \\
(\mathrm{mm})\end{array}$ & $\begin{array}{c}\text { Soluble } \\
\text { solids } \\
\text { concn } \\
(\%)\end{array}$ & $\begin{array}{c}\text { Pedical } \\
\text { diam } \\
(\mathrm{mm})\end{array}$ & $\begin{array}{c}\text { Pedica } \\
\text { length } \\
(\mathrm{mm})\end{array}$ \\
\hline Days to first ripened fruit & & -0.48 & 0.16 & 0.31 & -0.27 & -0.34 & 0.24 & -0.07 & 0.14 & 0.19 \\
\hline Plant height $(\mathrm{cm})$ & -0.45 & & -0.32 & -0.45 & -0.03 & 0.32 & -0.41 & 0.06 & -0.46 & -0.16 \\
\hline Fruit weight (g) & 0.07 & -0.45 & & 0.67 & 0.24 & -0.32 & 0.63 & -0.08 & 0.68 & 0.26 \\
\hline Fruit diameter $(\mathrm{mm})$ & 0.18 & -0.48 & 0.89 & & -0.11 & -0.78 & 0.86 & -0.03 & 0.79 & 0.09 \\
\hline Fruit length (mm) & -0.30 & -0.01 & 0.23 & -0.12 & & 0.65 & -0.12 & -0.06 & 0.25 & 0.28 \\
\hline Fruit shape ${ }^{z}$ & -0.29 & 0.34 & -0.50 & -0.70 & 0.65 & & -0.70 & 0.00 & -0.43 & 0.06 \\
\hline Pericarp thickness (mm) & 0.16 & -0.44 & 0.85 & 0.85 & -0.04 & -0.65 & & -0.14 & 0.75 & 0.18 \\
\hline Soluble solids concn. (\%) & 0.07 & 0.14 & -0.43 & -0.37 & -0.03 & 0.26 & -0.46 & & -0.08 & 0.09 \\
\hline Pedicel diameter $(\mathrm{mm})$ & 0.05 & -0.50 & 0.85 & 0.79 & 0.24 & -0.42 & 0.76 & -0.45 & & 0.10 \\
\hline Pedicel length (mm) & 0.13 & -0.15 & 0.06 & -0.01 & 0.22 & 0.10 & 0.09 & 0.09 & 0.10 & \\
\hline
\end{tabular}

${ }^{\mathrm{z} R a t i o}$ of fruit length to fruit diameter.

in breeding for large-fruited peppers, would allow efficient selection for large-fruited progeny. Previous studies in which fruit size and dimensions were measured have also indicated additivity of these characters (Lippert, 1975; Setiamihardja and Knavel, 1990; Thakur et al., 1980).

The high positive genetic correlations of fruit weight with fruit diameter and pericarp thickness, and its low correlation with fruit length indicated that the width of the fruit and the thickness of its pericarp are the most important determinants of fruit size in the 'Maor' $x$ 'Perennial' cross. The high genetic correlations between fruit and pedicel diameters, as well as with pericarp thickness, suggest that common or linked genes control these traits. In contrast, the genetic correlations between fruit diameter and fruit length as well as between pedicel diameter and pedicel length were low. Similarly, correlations between fruit length and pedicel length and between plant height and fruit length were low. Low correlation between length and width of the fruit was also found by Kaiser (1935). A high correlation between fruit weight and fruit diameter was also noted by Legg and Lippert, (1966). Similarly, a positive correlation between fruit and pedicel diameter was reported by Setiamihardja and Knavel (1990).

The negative correlation between plant height and fruit maturity observed in the present study is in agreement with a reported high negative correlation between these traits in the Poaceae (Xu, 1997). Similarly, the negative correlation between total soluble solids and pericarp thickness observed in the present study is in agreement with the negative correlation found between total soluble solids and fruit size in tomato (Stevens, 1986). The moderate negative correlation between total soluble solids and both pericarp thickness and fruit weight, indicates that it should be possible to introgress genes efficiently that increase soluble solids concentration from 'Perennial' while maintaining large fruit of sweet blocky breeding lines.

\section{Literature Cited}

Bernacchi, D., T. Beck-Bunn, Y. Eshec, J. Lopez, V. Petiard, J. Uhlig, D. Zamir, and S. Tanksley. 1998. Advanced backcross QTL analysis in tomato. I. Identification of QTLs for traits of agronomic importance from Lycopersicon hirsutum. Theor. Appl. Genet. 97:381-397.

Cahaner, A. and J. Hillel. 1980. Estimating heritability and genetic correlation between traits from generations $\mathrm{F}_{2}$ and $\mathrm{F}_{3}$ of self-fertilizing species: Comparison of three methods. Theor. Appl. Genet. 58:33-38.

Caranta, C., A. Palloix, and V. Lefebvre.1997. QTLs for a component of partial resistance to cucumber mosaic virus in pepper: Restriction of virus installation in host-cell. Theor. Appl. Genet. 94:431-438.

Daubeze, A.M.,J.W.Hennart, and A.Palloix. 1995. Resistance to Leveillula taurica in pepper (Capsicum annuum) is oligogenically controlled and stable in Mediterranean regions. Plant Breeding 114:327-332.

Deshpande, R.B. 1933. Studies in Indian chillies. III. The inheritance of some characters in Capsicum annuum L. Indian J. Agr. Sci. 3:219-300.

Kaiser, S. 1935. The factors governing shape and size in Capsicum fruits: A genetic and developmental analysis. Torrey Bot. Club Bul. 62: 433454.

Khambanonda, I. 1950. Quantitative inheritance of fruit size in red pepper (Capsicum frutescens L.) Genetics 35:322-343.

Lapidot, M., I. Paran, R. Ben-Joseph, S. Ben-Harush, M. Pilowsky, S. Cohen, and C. Shifriss.1997. Tolerance to cucumber mosaic virus in pepper: Development of advanced breeding lines and evaluation of virus level. Plant Dis. 81:185-188.

Lefebvre, V., A. Palloix, C. Caranta, and E. Pochard. 1995. Construction of an intra-specific integrated linkage map of pepper using molecular markers and doubled-haploid progenies. Genome 38:112-121.

Legg, P.D. and L.F. Lippert. 1966. Estimates of genetic and environmental variability in a cross between two strains of pepper (Capsicum annuиm L.). Proc. Amer. Soc. Hort. Sci. 89:443-448.

Lippert, L.F. 1975. Heterosis and combining ability in chilli pepper by diallel analysis. Crop Sci. 15:323-325.

McArdle, R.N. and J. C. Bouwkamp. 1983. Inheritance of several fruit characters in Capsicum annuum L. J. Hered. 74:125-127.

Meshram, L.D. and A.M. Mukewar. 1986. Heterosis studies in Chilli (Capsicum annuum L.). Sci. Hort. 28:219-225.

Paran, I., E. Aftergoot, and C. Shifriss. 1998. Variation in Capsicum annuum revealed by RAPD and AFLP markers. Euphytica 99:167-173.

Peterson P.A. 1959. Linkage of fruit shape and color genes in Capsicum. Genetics 44:407-419.

SAS Institute, Inc. 1995. JMP users guide: Version 3.1 of JMP. SAS Inst., Inc., Cary, N.C.

Setiamihardja, R. and D.E. Knavel. 1990. Association of pedicel length and diameter with fruit length and diameter and ease of fruit detachment in pepper. J. Amer. Soc. Hort. Sci. 115:677-681.

Singh, J. 1992. Breeding multiple resistant lines in chilli pepper at Pau Ludhiana. VIII: Meeting on Genetics and Breeding on Capsicum and Eggplant. Rome, Italy p. 127-131.

Stevens, M.A.1986. Inheritance of tomato fruit quality components. Plant Breeding Rev. 4:273-311.

Thakur, P.C., H.S. Gill, and P.M. Bhagchandani. 1980. Diallel analysis of some quantitative traits in sweet pepper. Indian J. Agr. Sci. 50:811-817.

Xiao, J., S. Grandillo, S.N. Ahn, S.R. McCouch, S.D. Tanksley, J. Li, and L. Yuan. 1996. Genes from wild rice improve yield. Nature 384:223-224. Xu, Y. 1997. Quantitative trait loci: Separating, pyramiding, and cloning. Plant Breeding Rev. 15:85-139. 